\title{
Dynamic Simulation of Pure Hydrogen Production via ethanol Steam Reforming in a Catalytic Membrane Reactor
}

\author{
Ali Hedayati $^{\star a b}$, Olivier Le Corre ${ }^{a}$, Bruno Lacarrière ${ }^{a}$, Jordi Llorca ${ }^{b}$
}

a Department of energy systems and environment, Ecole des Mines de Nantes, 4 Rue Alfred Kastler,44307 Nantes, France. ali.hedayati@mines-nantes.fr

a Department of energy systems and environment, Ecole des Mines de Nantes, 4 Rue Alfred Kastler, 44307Nantes, France. Olivier.Le-Corre@mines-nantes.fr

a Department of energy systems and environment, Ecole des Mines de Nantes, 4 Rue Alfred Kastler, 44307Nantes, France. Bruno.Lacarriere@mines-nantes.fr

b Institute of Energy Technologies, Universitat Politècnica de Catalunya, Diagonal 647, ETSEIB, 08028 Barcelona, Spain. jordi.llorca@upc.edu

*corresponding author: Ali Hedayati:

ali.hedayati@mines-nantes.fr, Department of energy systems and environment, Ecole des Mines de Nantes, 4 Rue Alfred Kastler, 44307Nantes, France.

ali.hedayati@upc.edu, Institute of Energy Technologies, Universitat Politècnica de Catalunya, Diagonal 647, ETSEIB, Pav. C, 08028 Barcelona, Spain.

\section{Abstract}

Ethanol steam reforming (ESR) was performed over $\mathrm{Pd}-\mathrm{Rh} / \mathrm{CeO}_{2}$ catalyst in a catalytic membrane reactor (CMR) as a reformer unit for production of fuel cell grade pure hydrogen. Experiments were performed at $923 \mathrm{~K}, 6-10 \mathrm{bar}$, and fuel flow rates of 50 to $200 \mu \mathrm{l} / \mathrm{min}$ using a mixture of ethanol and distilled water with steam to carbon ratio of 3. A static model for the catalytic zone was derived from the Arrhenius law to calculate the total molar production rates of ESR products, i.e. $\mathrm{CO}, \mathrm{CO}_{2}, \mathrm{CH}_{4}, \mathrm{H}_{2}$, and $\mathrm{H}_{2} \mathrm{O}$ in the catalytic zone of the CMR (coefficient of determination $\left.\mathrm{R}^{2}=0.993\right)$. The pure hydrogen production rate at steady state conditions was modeled by means of a static model based on the Sieverts' law. Finally, a dynamic model was developed under ideal gas law assumptions to simulate the dynamics of pure hydrogen production rate in the case of the fuel flow rate or the operational pressure set point adjustment (transient state) at isothermal conditions. The simulation of fuel flow rate change dynamics was more essential compared to the pressure change one, as the system responds much faster to such an adjustment. The results of the dynamic simulation fitted very well to the experimental 
40 values, which proved the robustness of the simulation based on the Sieverts' law. The

41 simulation presented in this work is similar to the hydrogen flow rate adjustments needed to set

42 the electrical load of a fuel cell, when fed online by the pure hydrogen generating reformer

43 studied.

44

45 Keywords:

46 Ethanol Steam Reforming, Pure hydrogen production, Membrane reactor, Dynamic simulation,

47 Sieverts' law

Highlights:

- Ethanol steam reforming (ESR) experiments were performed in a Pd-Ag membrane reactor

- The model of the catalytic zone of the reactor was derived from the Arrhenius law

- The permeation zone (membrane) was modeled based on the Sieverts' law

- A dynamic model was developed under ideal gas law assumptions

- Pressure and fuel flow rate adjustments were considered for dynamic simulation

\section{Introduction}

59 Renewable energy resources are now considered as one of the fastest and most feasible

60 solution to achieve the targets of clean electricity production; however, some challenges such

61 as dependency on the geographical and local conditions and infrastructures, and transmission

62 of produced electricity to the end users remain among the challenges to be encountered. In this

63 regard, on-site electricity production at the place/time where needed is beneficial. 
65 Being compatible with modern energy carriers such as hydrogen, fuel cells are considered as

66 the efficient (45-50\% electrical efficiency) and environmentally friendly energy convertors of the

67 future power generation systems [1-3]. Fuel cells have proved potentials in different

68 applications and can be applied in sub-MW size at any condition, independent from

69 geographical factors such as local climate conditions. Although production of hydrogen-rich

70 gases can offer flexible fuels for fuel cells [4], the pollution-free efficient performance of a fuel

71 cell is reached when pure hydrogen is used [5]. Accordingly, the main challenge remains in the

72 requirements of the special installations and infrastructures for production, distribution, and

73 delivery of hydrogen as it is needed in highly pure state [6]. Production of hydrogen - for

74 example via reforming processes - at the same place/time needed can make pure hydrogen

75 storage/transportation unnecessary [7].

77 The use of renewable biofuels such as bio-ethanol as a source of hydrogen is highly beneficial

78 due to the higher $\mathrm{H} / \mathrm{C}$ ratio, lower toxicity, and higher safety of storage that distinguishes ethanol

79 over other substrates. Bio-ethanol is cheaply and easily obtained from biomass and organic

80 waste and can be used directly in catalytic steam reforming processes to produce hydrogen

81 since it contains large amounts of water [8]. Concerning the production of fuel cell grade

82 hydrogen, the application of catalytic membrane reactors (CMRs) is beneficial where the

83 production and separation of hydrogen from the mixture of produced gases take place in the

84 same reactor vessel simultaneously. In the case of Pd-Ag metallic membrane reactors,

85 hydrogen purity up to $99.999 \%$ is obtained, which is suitable for direct low-temperature fuel cell 86 feeding $[9,10]$.

88 The application of the CMRs in pure hydrogen production (as a reformer unit) is still under

89 investigation. The effect of the co-presence of steam reforming bybroducts $\left(\mathrm{CO}, \mathrm{H}_{2} \mathrm{O}, \mathrm{CO}_{2}\right.$ and

$90 \mathrm{CH}_{4}$ ) on the performance of the membrane in terms of pure hydrogen permeation rate is still a 
91 challenge to be overcome. Hou et al. [11] reported that the hydrogen inhibition effect of $\mathrm{CO}$,

$92 \mathrm{CO}_{2}$, and $\mathrm{H}_{2} \mathrm{O}$ in the case of a Pd-Ag membrane could be classified as $\mathrm{H}_{2} \mathrm{O}>\mathrm{CO}>>\mathrm{CO}_{2}$ in terms

93 of the competitive adsorption capability of the gases on the Pd-Ag membrane surface. In the

94 study by Unemoto et al. [12] the comparison between $\mathrm{CO}, \mathrm{CO}_{2}$, and $\mathrm{H}_{2} \mathrm{O}$ showed that at $\mathrm{T}<600$

$95 \mathrm{~K}, \mathrm{CO}$ had the strongest influence on the hydrogen permeability of the Pd membrane. They

96 suggested that at $\mathrm{T}>873 \mathrm{~K}$, the effect of co-existence of other species for a membrane with a

97 thickness higher than $10 \mu \mathrm{m}$ is negligible. On the contrary, Patrascu and Sheintuch [13]

98 concluded that the effect of very small amount of $\mathrm{CO}$ on hydrogen permeation inhibition could

99 be notable even in presence of $\mathrm{H}_{2} \mathrm{O}$. The strong effect of low concentration of $\mathrm{CO}$ on the

100 membrane permeation behavior at different temperatures was reported also in other studies

101 [14-18]. Catalano et al. [19] stated that $\mathrm{CH}_{4}$ acted as inert gases in terms of hydrogen inhibition.

102 Barreiro et al. [20] showed that the hydrogen flux was reduced in presence of water at 593-723

$103 \mathrm{~K}$, while $\mathrm{CO}_{2}$ had no influence on the permeation rate of hydrogen.

105 Overall, the literature does not provide a consistent idea on the hydrogen inhibition

106 phenomenon due to the competitive adsorption of $\mathrm{CO}$ and $\mathrm{H}_{2} \mathrm{O}$ on the surface of the metallic $\mathrm{Pd}$

107 membrane, the effect of reverse reactions of water gas shift (WGS) and methane steam

108 reforming (MSR), and the effect of operating at high pressure and temperature in the real

109 atmosphere of the ESR. It is not totally agreed if $\mathrm{CO}_{2}$ and $\mathrm{CH}_{4}$ are considered as inert gases as

110 their reactions with water via reverse WGS and MSR can lead to a more complicated situation

111 regarding the influence on the hydrogen permeation. According to the review given by Cornaglia

112 et al. [21], it can be understood that the hydrogen inhibition phenomenon caused by the ESR

113 products especially in presence of $\mathrm{H}_{2} \mathrm{O}$, is a very complicated issue. It is inevitable to study each

114 fuel reformer system specifically in terms of the properties of the membrane, operating

115 conditions, and the composition of the fuel fed into the reformer reactor. 
117 If a fuel cell is fed online by pure hydrogen generating system (hereafter referred to as

118 "reformer"), the dynamics of pure hydrogen supply must be fitted to the load variations (dynamic

119 behavior) of a fuel cell. Considering the dynamic energy demand of an end user - for example a

120 building - a reformer must be able to realize and track the dynamic electrical output of the fuel

121 cell in charge of electricity supply of the end user. Adjustment of the flow rate of pure hydrogen

122 provided by a reformer is a crucial phase to respond promptly and aptly to the electrical load

123 modifications of a fuel cell, aiming to optimize the whole system (reformer + fuel cell)

124 performance. Although a few studies are reported in the literature regarding the dynamic

125 performance of the fuel cells, the works devoted to the investigations of the dynamic

126 performance of the online fuel reformers - corresponding to the load variation of the fuel cells -

127 are not sufficiently reported in the literature [22].

129 Garcia et al. [23] developed a dynamic model for a three module reformer made up of ethanol

130 dehydrogenation, acetaldehyde steam reforming, and water gas shift units for feeding hydrogen

131 to a fuel cell. They simulated the dynamic response of the reforming unit in terms of the

132 selectivity of the products of the ESR reaction rate to the changes in concentration of the feed

133 (ethanol + water). The same authors in another study [24] focused on the controllability and the

134 dynamics simulation of the same system as they reported in [23] by acting on the feed

135 concentration at isothermal conditions. A dynamic numerical model for the methane fuel

136 processor of a PEMFC was developed by Funke et al. [25] aiming at optimizing the reaction

137 conditions and heat integration especially during start up, shut down, and load change. The

138 effect of two constructions (the reactor and the evaporator with and without thermal coupling) on

139 the temperature profile, reaction rates, and methane conversion was investigated and it was

140 reported that hydrogen yield is higher when the reactor and the evaporator are not thermally

141 coupled. John and Schroer [26] presented a dynamic model of a methane steam reformer for a

142 residential fuel cell system. The dynamic model covered the full operating range including the 
143 startup and shut down, and described the dynamics of the hydrogen yield and thermal behavior

144 of the reformer when the flow rate of water or natural gas changed. The thermal system was

145 affected by increasing the flow rate of the water. Higher hydrogen yield and lower methane

146 concentration at the outlet were reported at higher temperature, i.e. lower concentration of inlet

147 water. A dynamic model for an interconnected reformer and PEMFC stack was developed by

148 Stamps and Gatzke [27] with emphasis on the influence of various design and operating

149 parameters on system performance. It was concluded that operating at higher temperature

150 results in higher system performance.

152 A dynamic modeling study of a catalytic steam reformer by Kvamsdal et al. [28] showed that 153 the steam or gas $\left(\mathrm{CO}, \mathrm{CO}_{2}, \mathrm{H}_{2}\right.$, and $\left.\mathrm{CH}_{4}\right)$ supply interruption affects the reactor wall

154 temperature, which can directly lead to material failure or coke formation. Lin et al. [29] modeled 155 the dynamics of an experimental multi stage methane reformer in charge of providing hydrogen

156 to a PEMFC to design a control system to provide the responsiveness of the fuel reformer to the

157 alterations in the hydrogen demand. The response of the fuel reformer to changes in the

158 process variables such as $\mathrm{CH}_{4}$ feed flow rate, $\mathrm{H}_{2} \mathrm{O} / \mathrm{CH}_{4}$ feed ratio, $\mathrm{O}_{2} / \mathrm{CH}_{4}$ feed ratio and the

159 reformer inlet temperature was studied. Tsourapas et al. [30] presented a dynamic model based

160 on thermodynamics and energy balance for a JP5 fuel reformer in connection with a membrane 161 separator (SEP) and a PEM fuel cell to investigate the effects of the operating set point of SEP

162 on the overall system efficiency. They concluded that the open loop response of the system is

163 shown to be satisfactory in terms of the response time and hydrogen production. It was shown

164 that there is a trade-off between the SEP efficiency and the overall efficiency of the system.

166 In another work by Koch et al. [10], a dynamic model of an ethanol steam reformer (as the fuel 167 reformer for pure hydrogen production to feed a PEMFC) was developed to implement an 168 adaptive and predictive control. The static behavior of the reformer system was described by 
means of several maps developed in Matlab. Further, the dynamics of the fuel reformer in

170 connection with a PEMFC by acting upon reactor pressure and feed flow rate (ethanol + water)

171 was studied. They proposed an efficient controller that reduced the response time of the

172 reformer by a factor of 7 down to $8 \mathrm{~s}$ in terms of following the dynamics of a fuel cell load by

173 acting simultaneously on the fuel flow rate and pressure. However, such advanced controllers

174 require internal models and simulations for further development.

176 The purpose of this paper is to present a simpler approach mainly based on physical laws

177 (adapted Arrhenius model, mass balance, ideal gas law, and Sieverts' law). Such a model can

178 be applied for the development of controllers, which is out of the scope of the paper. A dynamic

179 model of a reforming system (the CMR) is given to simulate the dynamics of the pure hydrogen

180 production rate at unsteady state conditions (between two steady state points) under fuel flow

181 rate and pressure set-up steps. The model considers the kinetics of the catalytic reforming

182 reactions regarding the molar production of ESR products, especially hydrogen inside the

183 reactor at unsteady operating conditions. Moreover, the dynamic simulation is based on the real

184 dynamic experiments using a Pd-Ag membrane reactor module (where production and

185 separation of hydrogen takes place in the same reactor) for production of fuel cell grade

186 hydrogen via ethanol steam reforming. Additionally, application of the CMR makes it possible to

187 investigate the effect of the byproducts of the ESR $\left(\mathrm{CO}, \mathrm{CO}_{2}, \mathrm{H}_{2} \mathrm{O}\right.$, and $\left.\mathrm{CH}_{4}\right)$ on the

188 performance of a real case Pd-Ag membrane based on the observed reaction kinetics

189 (concentration of the ESR products). The latter is an important factor in monitoring and

190 simulation of the performance of the membrane in ESR environment so that many works have

191 been reported on the investigation of the effect of the gaseous byproducts on the permeation

192 behavior of the membranes. 
198 The $\mathrm{Pd}-\mathrm{Rh} / \mathrm{CeO}_{2}$ catalyst $(0.5 \% \mathrm{Pd}-0.5 \% \mathrm{Rh})$ was deposited over cordierite pellets of about 1

$199 \mathrm{~mm}$ following the procedure described by López et al. [31]. When ESR is performed over Pd-

$200 \mathrm{Rh} / \mathrm{CeO}_{2}$ catalyst, the major reforming reactions are [32,33]:

$201 \quad \mathrm{C}_{2} \mathrm{H}_{5} \mathrm{OH} \rightarrow \mathrm{H}_{2}+\mathrm{CO}+\mathrm{CH}_{4}$

$202 \mathrm{CO}+\mathrm{H}_{2} \mathrm{O} \leftrightarrows \mathrm{H}_{2}+\mathrm{CO}_{2}$

$203 \quad \mathrm{CH}_{4}+2 \mathrm{H}_{2} \mathrm{O} \leftrightarrows 4 \mathrm{H}_{2}+\mathrm{CO}_{2}$

$204 \quad \mathrm{C}_{2} \mathrm{H}_{5} \mathrm{OH}+3 \mathrm{H}_{2} \mathrm{O} \leftrightarrow 2 \mathrm{CO}_{2}+6 \mathrm{H}_{2}$

206 Equations 1-3 represent the ethanol decomposition, water gas shift, and methane steam

207 reforming reactions, respectively. Equation 4 is the overall ESR reaction.

209 The laboratory setup used for the ESR experiments (fuel reformer) consisted essentially of a

210 fuel tank, a liquid pump, a CMR, a pressure transducer and a condenser. A detailed description

211 of the reformer setup can be found in [34]. A schematic plan of the fuel reformer system is 212 shown in Fig. 1.

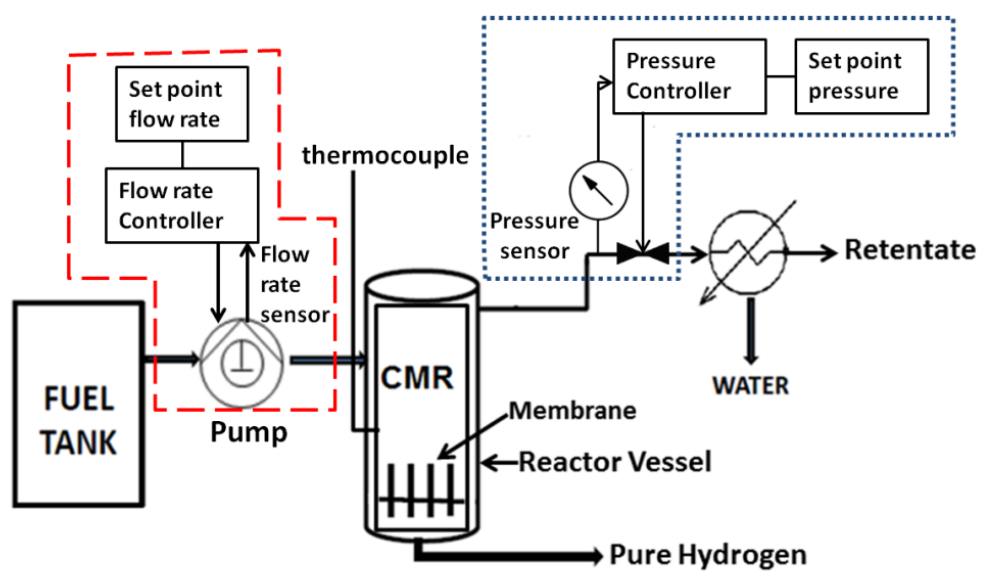

Fig. 1. Scheme of the Reformer. 
216 The dashed and dotted lines represent the fuel flow rate and pressure controlling systems,

217 respectively. The CMR (provided by Reb Research and Consulting [35]) was 10 in. tall and 1 in.

218 in diameter. There were four Pd-Ag membrane tubes selective to hydrogen inside the reactor;

219 each one 3 in. tall and 1/8 in. diameter in order to separate hydrogen from the gases produced.

220 To perform the experiments, the reactor was filled with the catalysts so that the metallic

221 membranes were fully covered. The retentate pressure was adjusted by a back-pressure

222 regulator (transducer). No pressure regulation was implemented on the permeate side and no

223 sweep gas was used so that pure hydrogen was obtained at atmospheric pressure. The flow

224 rate of pure hydrogen (permeate) was measured with a mass flow meter and fluctuated within

$225 \pm 2 \mathrm{ml} / \mathrm{min}$. The composition of retentate gases (waste gases) was analyzed on a dry basis using

226 an online Gas Chromatograph ( $\pm 3 \%$ ) (Agilent 3000A MicroGC using MS $5 \AA$, PlotU and

227 Stabilwax columns) every 4 minutes.

229 The operating conditions of the experiments under steady conditions are summarized in Table

230 1. The experiments were performed at isothermal conditions.

Table 1. Experimental conditions

\begin{tabular}{lc}
\hline Temperature $T^{\text {set point }}(\mathrm{K})$ & 923 \\
Pressure $P^{\text {set point }}(\mathrm{bar})$ & $6-10$ \\
Fuel flow rate $F_{F}^{\text {set point }}(\mu \mathrm{l} / \mathrm{min})$ & $50-200$ \\
Steam to carbon ratio SC & 3
\end{tabular}

234 At $923 \mathrm{~K}$, the $\mathrm{ESR}$ over the $\mathrm{Pd}-\mathrm{Rh} / \mathrm{CeO}_{2}$ catalyst is optimized in terms of hydrogen selectivity,

235 hydrogen recovery, and ethanol conversion [31,32,36,37]. At SC ratio of 3, the highest value of

236 hydrogen recovery was obtained during the experimental work that is attributed to the 
237 availability of water for the reforming reactions. On the other hand, coke formation is less prone

238 to occur at a higher SC ratio with respect to the stoichiometric value.

239

240 Two types of dynamic tests were performed in this study: pressure change and flow rate

241 change. In the case of pressure change dynamic tests, both increasing and decreasing steps

242 were considered. As presented in Fig. 2, the pressures range of 7-10 bar was selected because

243 at these pressures the efficiency of the fuel reformer is maximum [38].

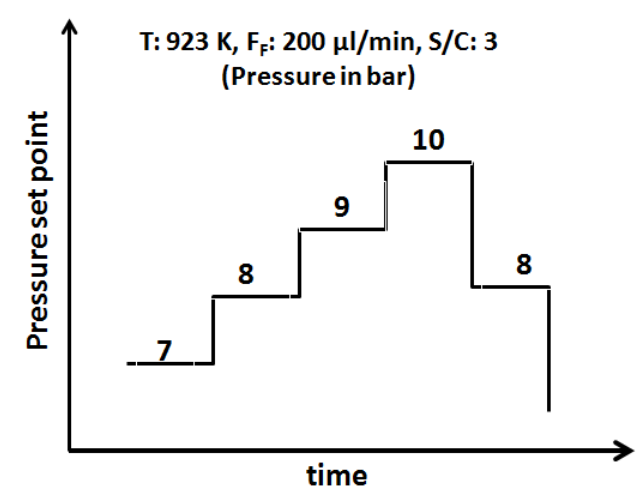

Fig. 2. Scheme of the pressure change for the dynamic tests.

249 Dynamic tests regarding the response of the system to the fuel flow rate changes were

250 performed through intervals of $50 \mu \mathrm{l} / \mathrm{min}$ as shown in Fig. 3. 


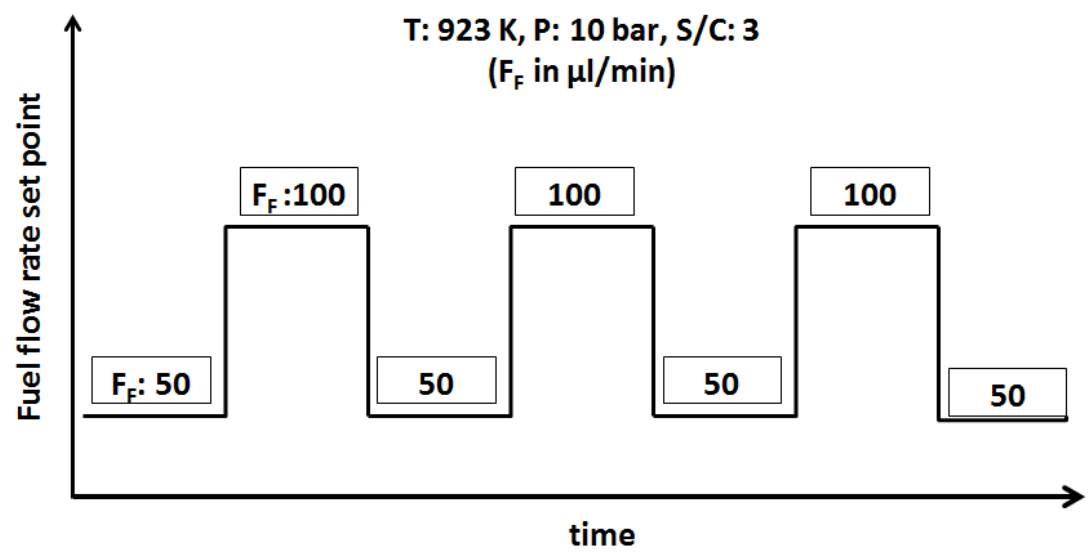

Fig. 3. Scheme of the fuel flow rate change for the dynamic tests.

255 The changing cycles were run more than one time to observe the durability of the performance

256 of the reforming system. According to the membrane limitations, higher flow rates were not

257 taken into account.

258

259 2.2. CMR isothermal model

261 For the modeling task, the CMR was divided into two sections, i.e. the catalytic zone, and the 262 permeation zone (the membrane) as shown in the Fig. 4. The ESR reactions were supposed to 263 occur in the catalytic zone, resulting in total production of the retentate gas plus the permeated 264 hydrogen. The permeation zone (the membrane) stands for the pure hydrogen generating step

265 for which the dynamic model was developed. The outputs of the catalytic zone model were used 266 as the input of the static models of the permeation zone (i.e. the membrane). 


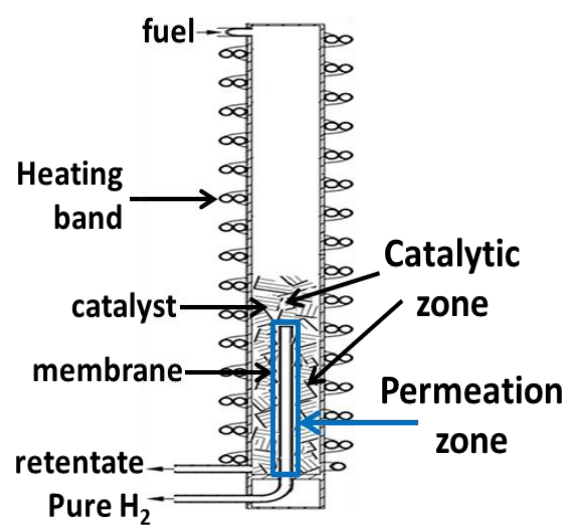

Fig. 4. The catalytic zone and the permeation zone of the CMR

271 It is assumed that the fuel (ethanol+water) is in its gas phase at the entrance of the volume of

272 the CMR and the ideal gas law is applied. The CMR model is splitted into a static model and a

273 first oder transfer function, i.e. ESR products are driven by the operating conditions (pressure

274 and temperature) under steady state conditions.

\subsubsection{Static model of the catalytic zone}

278 A static model for the catalytic zone was developed to calculate the total molar production rate

279 of species present in the catalytic zone of the $\mathrm{CMR}$, i.e. $\mathrm{CO}, \mathrm{CO}_{2}, \mathrm{CH}_{4}, \mathrm{H}_{2}$, and $\mathrm{H}_{2} \mathrm{O}$ as the

280 products of the catalytic conversion of ethanol (around the membrane). The static model was

281 derived following the Arrhenius law as a function of fuel flow rate and operating pressure in the 282 form of:

$284 \dot{\mathrm{n}}_{\text {specie }}=f_{\text {specie }} \times \exp \left(-\frac{g_{\text {specie }}}{R T}\right)$

$285 f_{\text {specie }}=\alpha_{\text {specie }} \times F_{F}^{\beta_{\text {specie }}}$

$$
g_{\text {specie }}=\theta_{\text {specie }} \times P+\gamma_{\text {specie }}
$$


$288 \dot{\mathrm{n}}_{\text {specie }}[\mathrm{mol} / \mathrm{s}]$ is the molar production rate of each species produced in the CMR via ESR over

289 the catalyst (and around the membrane). $\mathrm{F}_{\mathrm{F}}\left[\mathrm{m}^{3} / \mathrm{s}\right]$ and $\mathrm{P}[\mathrm{Pa}]$ represent the fuel (ethanol +

290 water) flow rate and the reactor pressure, respectively. ' $f_{\text {specie }}$ ' represents a function of fuel flow

291 rate as pre-exponential factor, and ' $g_{\text {specie }}$ ' represents the energy of activation as a function of

292 pressure. $\alpha_{\text {specie }}, \beta_{\text {specie }}, \theta_{\text {specie }}$, and $\gamma_{\text {specie }}$ are the fitting parameters of the equations. The

293 introduced model was applied to calculate the molar production rate of the ESR products,

294 mainly to calculate the partial pressure of hydrogen $\left(\mathrm{P}_{\mathrm{H} 2, \mathrm{r}}\right.$ in eq. 9) around the membrane

295 surface (right before the permeation zone).

\subsubsection{Static models of the permeation zone}

299 The model of hydrogen permeation through the membrane at steady state was derived from the

300 Sieverts' law. Hydrogen permeation phenomenon through a Pd-Ag membrane is explained by

301 Sieverts' law based on the mass transfer and surface reactions principals [19,39]. As stated by

302 the Sieverts' law, the hydrogen permeation rate through Pd-Ag membrane is a temperature

303 activated phenomena driven by the difference between the partial pressure of hydrogen at two

304 sides, i.e. the retentate side (inside the reactor, around the membrane) and the permeate side

305 (right after the membrane) [31,33]:

306

$307 J_{H 2}=\frac{Q_{0}}{\delta} e^{\frac{-E_{a}}{R T}}\left(\sqrt{P_{H 2, r}}-\sqrt{P_{H 2, p e r m}}\right)$

309 Where $\mathrm{J}_{\mathrm{H} 2}$ is the pure hydrogen production rate obtained via the Sieverts' law. $\delta$ is the thickness

310 of the membrane and $Q_{0}$ is the pre-exponential factor. $\mathrm{E}_{\mathrm{a}}, R$, and $\mathrm{T}$ are the activation energy,

311 universal gas constant, and temperature, respectively. $P_{H 2, r}$ and $P_{H 2, \text { perm }}$ are the partial pressure

312 of hydrogen at the retentate and permeate side, respectively. 
313 The partial pressure of hydrogen inside the reactor was calculated based on the hydrogen

314 fraction in the gas phase assuming that the only present species in the catalytic bed (and

315 around the membrane) are $\mathrm{CO}, \mathrm{CO}_{2}, \mathrm{CH}_{4}, \mathrm{H}_{2}$ and $\mathrm{H}_{2} \mathrm{O}$. Therefore:

$317 P_{H 2, r}=P \times y_{H 2, r}$

319 Where $\mathrm{P}$ and $\mathrm{y}_{\mathrm{H} 2, \mathrm{r}}$ represent the reactor pressure and the molar fraction of hydrogen in the 320 catalyst bed, respectively. The reactor pressure simulation method is explained in section 2.2.3.

321 The activation energy $\left(E_{a}\right)$ and the pre-exponential factor $\left(Q_{0}\right)$ are calculated by means of

322 permeation experiments during which pure hydrogen at known temperature and pressure is

323 purged and the permeation rate of hydrogen through the membrane is measured (atmospheric

324 pressure at the permeate side) [40-45].

326 As discussed before, the published open literature offers no robust model/analysis on the effect

327 of different species on the performance of the membrane in the real atmosphere of methane

328 steam reforming and water gas shift reactions. It was concluded that to understand the influence

329 of co-existence of ESR products on the permeation performance of the membrane, specific

330 models must be developed regarding specific operational conditions of the ESR environment.

332 Accordingly, a model was developed for hydrogen permeation through the Pd-Ag membrane;

333 specifically for the ESR environment at the operating conditions presented in this work. It is

334 assumed that the concentrations of $\mathrm{CO}$ and $\mathrm{H}_{2} \mathrm{O}$ affect the permeation performance of the

335 membrane differently at different operating conditions. The hidden effect of $\mathrm{CH}_{4}$ and $\mathrm{CO}_{2}$ are

336 taken into account considering the ESR reactions (eq. 1-3). Firstly, the model presented in the

337 section 2.2.1 (catalytic zone) was used to fit the molar flow rate of the species present in the

338 retentate gas, i.e. $\mathrm{CO}, \mathrm{CO}_{2}, \mathrm{CH}_{4}, \mathrm{H}_{2}$, and $\mathrm{H}_{2} \mathrm{O}$ (to calculate the partial pressure of hydrogen at 339 the retentate side). 
341 Regarding equation 9, the activation energy $\left(E_{a}\right)$ was taken from the work by Papadias et al.

342 [46] as they used the same membrane module as the one used in this work, with the same

343 characteristics and synthetized by the same manufacturer (REB Research \& Consulting [35]).

344 Therefore, the term $\frac{e^{\frac{-E a}{R T}}}{\delta}$ in eq. 9 was calculated, which is equal to $54.9\left[\mathrm{~m}^{-1}\right]$. Then, the term ' $\mathrm{Q}_{0}$ '

345 was obtained firstly from the experimental results $\left(Q_{0}^{\text {measure }}\right)$, and then modeled $\left(Q_{0}^{\text {model }}\right)$ by

346 means of a static model as a function of the reactor pressure $(P)$ and fuel flow rate $\left(F_{F}\right)$ :

$348 \quad Q_{0}^{\text {measure }}=\frac{J_{H 2} \times \delta}{e^{\frac{-E_{a}}{R T} \times\left(\sqrt{P_{H 2, r}}-\sqrt{P_{H 2, p e r m}}\right)}}$

$350 \quad Q_{0}^{\text {model }}=k_{1} \times F_{F} \times \exp \left(k_{2} \times P\right)$

352 Where ' $k_{i}$ ' is the fitting parameter. $\mathrm{P}_{\mathrm{H} 2, \mathrm{r}}$ in eq. 10 is obtained via eq. 9 by using the modeled

353 values of the molar production rate of ESR products (eq. 5-7) to calculate the hydrogen fraction

354 in the catalytic zone. In fact, this factor was used to fit the results of the Sieverts' law based

355 model to the experimental ones.

357 Accordingly, the hydrogen permeation rate at steady state conditions was modeled to be used

358 in the simulation of the dynamics of hydrogen permeation rate at transient conditions, i.e.

359 between two steady state points.

\subsubsection{Isothermal dynamic simulation of the permeation zone}

363 Prior to the dynamic simulation of the permeation zone, the reactor pressure was modeled in

364 the case of pressure set point adjustment during which the pressure valve of the reforming 
365 systems acts on the retentate gas flow rate to adjust to a higher or lower pressure. The ideal

366 gas law in the form of $\mathrm{PV}=\frac{\mathrm{mRT}}{\mathrm{M}_{\mathrm{W}}}$ was used to model the pressure of the reactor. $\mathrm{P}, \mathrm{V}, \mathrm{T}$, and $\mathrm{Mw}$

367 are reactor pressure, the volume of the reactor, reactor temperature, and the molar mass of the

368 fuel mixture, respectively. ' $m$ ' is the accumulated mass of the fuel added to the reactor volume.

369 It was assumed that the accumulation rate of the pumped fuel into the constant volume of the

370 reactor at constant temperature, results in pressure rise as the pressure valve acts on the outlet

371 of the system to block the retentate stream when pressure increase is required. Conversely, to

372 decrease the pressure, the pressure valve lets the retentate gas be released, so that the inlet

373 mass flow rate of the fuel gets lower than the outlet mass flow rate. Regardless of the action of

374 the pressure valve on the retentate gas stream, hydrogen constantly permeates through the

375 membrane. Therefore, the added mass to the reactor volume is the difference between the fuel

376 flow rate, and the retentate gas flow rate plus hydrogen permeation rate, so that:

$378 \quad \frac{d m}{d t}=\dot{\mathrm{m}}_{\text {fuel }}-\dot{\mathrm{m}}_{r}-\dot{\mathrm{m}}_{H 2 . p e r m}$

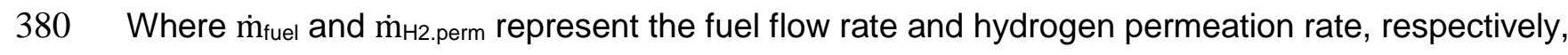
381 both in $[\mathrm{kg} / \mathrm{s}]$. Then, the ideal gas law is written as:

$383 \quad \frac{d P}{d t}=\left(\frac{R T}{V M_{W}}\right) \times \frac{d m}{d t}$

385 Where $\frac{\mathrm{dm}}{\mathrm{dt}}$ is the rate of the accumulation of the mass in the reactor volume. In this work, the 386 CMR is a packed bed reactor running at isothermal conditions, with negligible axial mixing. The 387 temperature and concentration difference is neglected, so that the models are considered as 388 ideal plug flow pseudo-homogenous ones [47]. 
390 The dynamic simulation was performed to predict the dynamic behavior of the pure hydrogen

391 production rate (permeate zone) in the transient periods during which the reforming system

392 alters between two steady state points, as a result of the fuel flow rate or operating pressure set

393 point adjustments. To develop the dynamic model of the permeate zone, a first order function

394 was used:

395

$396 \frac{J_{H 2}^{D}}{F_{F}}=\frac{J_{H 2}}{1+\tau S}$

397

$398 J_{H 2}^{D}$ is the pure hydrogen production rate obtained by the dynamic model. The superscript " $D$ "

399 stands for the dynamic model. $J_{H 2}$ represents the hydrogen permeation rate calculated via the

400 static model based on the Sieverts law, considering every single operating point as steady state.

401 The time constant is presented as $\tau$. The measured dynamic of fuel flow rate was faster than the

402 sampling time ( 1 second). Therefore, the fuel flow rate is always equal to its set point value:

403

$404 \quad F_{F}=F_{F}^{\text {set point }}$

405

406 Finally, equation 14 is written as:

407

$408 \quad \frac{J_{H 2}^{D}}{F_{F}^{\text {set point }}}=\frac{J_{H 2}}{1+\tau S}$

409

410 Where $\mathrm{F}_{\mathrm{F}}^{\text {set point }}$ is the fuel flow rate set point (see Fig. 3).

411

412 The simulation was performed by means of Ordinary Differential Equation (O.D.E) solver.

413

414 3. Results and discussion 
416 Least Square Method (LSM) was applied to obtain all the fitting parameters regarding the static

417 models. The time constant was estimated from a set of trials and errors.

\subsection{Static models of the permeation zone}

421 The products of ESR $\left(\mathrm{H}_{2}, \mathrm{CO}, \mathrm{CO}_{2}, \mathrm{CH}_{4}\right.$, and $\left.\mathrm{H}_{2} \mathrm{O}\right)$ and the pure hydrogen permeation rate was

422 modeled at four different fuel flow rates, i.e. 50, 100, 150, $200 \mu \mathrm{l} / \mathrm{min}$ and three different

423 pressures (6, 8, and 10 bar). As mentioned before, the molar production rate of all the ESR

424 products was needed in order to calculate the partial pressure of hydrogen in the catalytic zone

425 (around the membrane). The calculated molar production rates of the ESR products (catalytic

426 zone) are presented in Fig. 5. The dashed lines represent the 10\% error (discrepancy between

427 experiment and measurement). The x-axis (modeled) and y-axis (measured) are referred to the 428 values calculated by the static model and obtained via experiments, respectively.
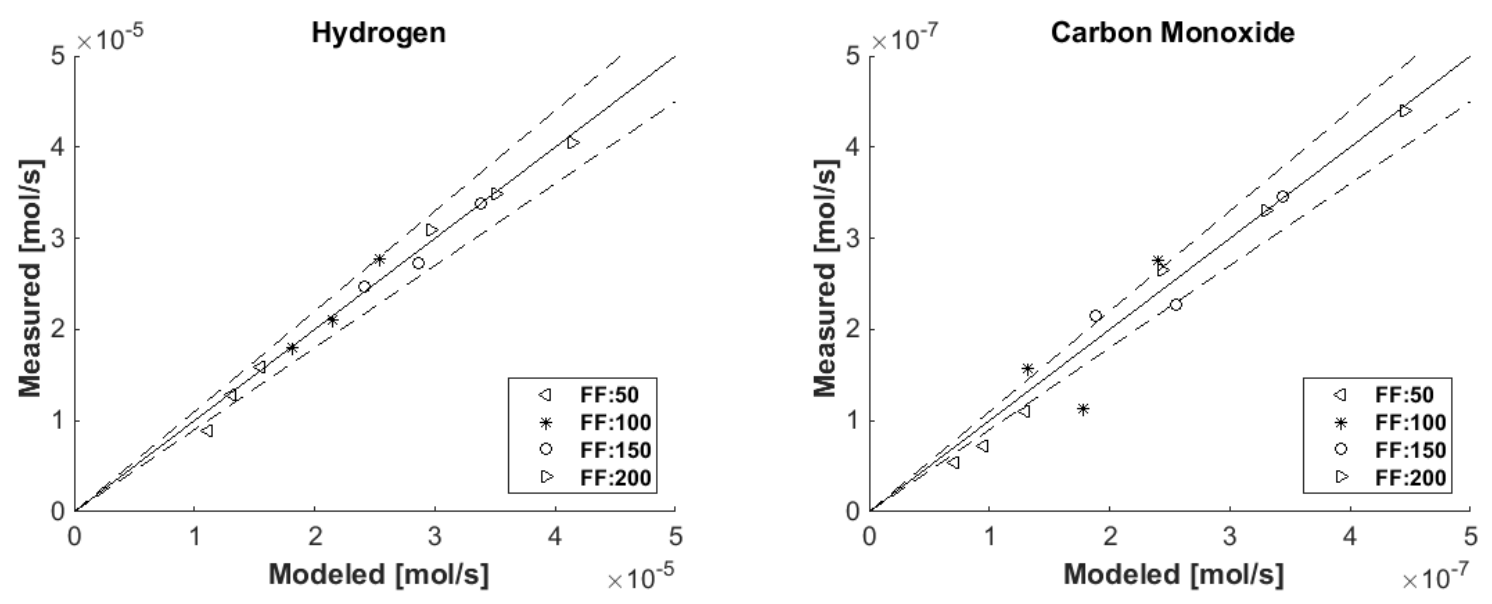

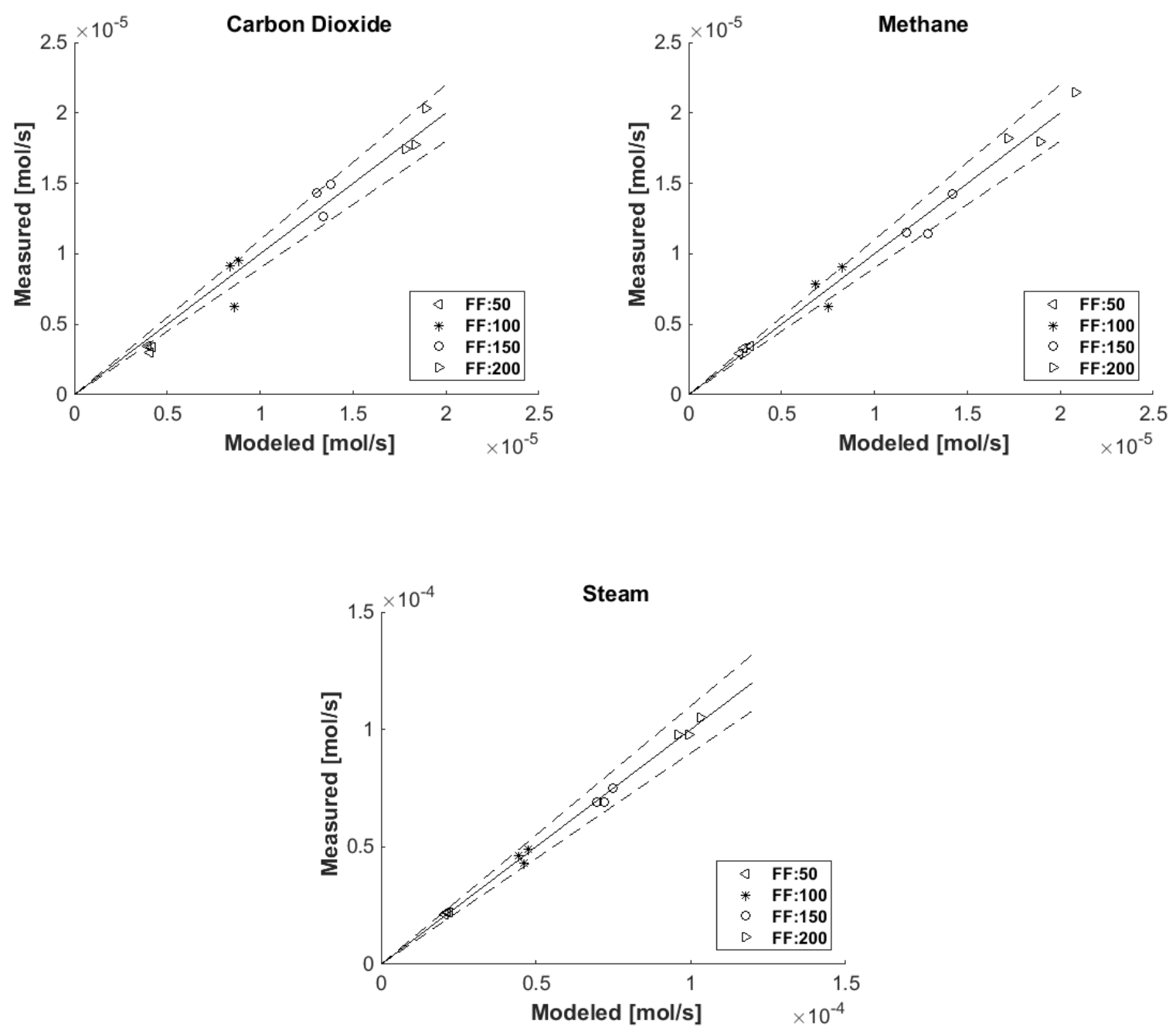

434

Fig. 5. Parity plots of the ESR products calculated by the static model (eq. 5-7).

435 The modeled values could fit the experimental results within the $10 \%$ error, especially in the

436 case of production rate of hydrogen. The values of the fitting parameters (eq. 6 and 7 ) for all the 437 gases are given in Table 2. 
442 Table 2. Fitting parameters of the static model for the ESR products production rate model (eq.

\begin{tabular}{|c|c|c|c|c|c|}
\hline specie & $\alpha_{\text {specie }}\left[\mathrm{mol}_{\mathrm{m}}{ }^{-3}\right]$ & $\beta_{\text {specie }}[-]$ & $\theta_{\text {specie }}\left[\mathrm{J} . \mathrm{mol}^{-1} . \mathrm{Pa}^{-1}\right]$ & $\gamma_{\text {specie }}\left[\mathrm{J} . \mathrm{mol}^{-1}\right]$ & $\mathrm{R}^{2}$ \\
\hline $\mathrm{H}_{2}$ & 1.0873 & 0.7096 & $8.3800 \times 10^{-7}$ & -0.0665 & 0.9954 \\
\hline $\mathrm{CO}$ & 75.5364 & 0.8930 & $-1.5028 \times 10^{-6}$ & -4.2727 & 0.9849 \\
\hline $\mathrm{CO}_{2}$ & 133.8928 & 1.0915 & $-1.4717 \times 10^{-7}$ & 1.1520 & 0.9911 \\
\hline $\mathrm{CH}_{4}$ & 560.2602 & 1.3303 & $-4.7941 \times 10^{-7}$ & 3.7000 & 0.9950 \\
\hline $\mathrm{H}_{2} \mathrm{O}$ & 226.0976 & 1.1131 & $-1.7989 \times 10^{-7}$ & 2.6771 & 0.9992 \\
\hline
\end{tabular}

445 Keeping in mind equations 5-7, it can be seen that the values of $\mathrm{P} \times \theta$ are very small compared 446 to $\mathrm{Y}$, except in the case of hydrogen. As mentioned before, the most effective factor on the

447 hydrogen permeation is the partial pressure of hydrogen in the reactor; hence, the value of $P \times \theta$

448 is higher in this case. The same explanation can be given regarding the parameter $\beta$. In the 449 case of hydrogen, the effect of pressure in the CMR configuration is dominant in comparison 450 with the fuel flow rate, resulting in the smallest value of $\beta$ in the case of hydrogen. Conversely, 451 the value of $\beta$ in the case of $\mathrm{CH}_{4}$ is the highest among the gases because the only source of $452 \mathrm{CH}_{4}$ is the ethanol decomposition reaction (eq. 1). At complete ethanol conversion, the higher 453 the fuel flow rate is, the higher the production rate of $\mathrm{CH}_{4}$ is. The value of $\beta$ in the case of $\mathrm{H}_{2} \mathrm{O}$ is 454 nearly one, which is very relevant since the ESR reaction were performed at $\mathrm{SC}=3$, where there 455 is a large amount of excess water. It can be concluded that the molar flow rate of water is 456 proportional to the inlet molar flow rate of water in the fuel mixture (ethanol + water). At $\mathrm{SC}=3$, a 457 large portion of the inlet water (70-90\%) leaves the reactor in the form of steam as unreacted 458 water. The value of $\theta$ in the case of $\mathrm{CO}$ is one order of magnitude smaller than other gases, 459 which is attributed to the very small amount of CO detected at the outlet of the reactor. The 460 values of $\theta$ proves that at higher pressures, less byproducts $\left(\mathrm{CO}, \mathrm{CO}_{2}, \mathrm{CH}_{4}\right.$, and $\left.\mathrm{H}_{2} \mathrm{O}\right)$ and more 
hydrogen are generated, which is totally in agreement with the experimental results and the aim

462 of application of the CMR, where ESR reactions are promoted (the shift effect).

463

464 The value of the pre-exponential factor model (eq. 11) showed a good correlation $\left(R^{2}=0.91\right)$ with 465 the calculated values (Fig. 6) except at $P=6$ bar; this is interpreted to the fact that at this 466 pressure the membrane starts to be effective for hydrogen separation.

467

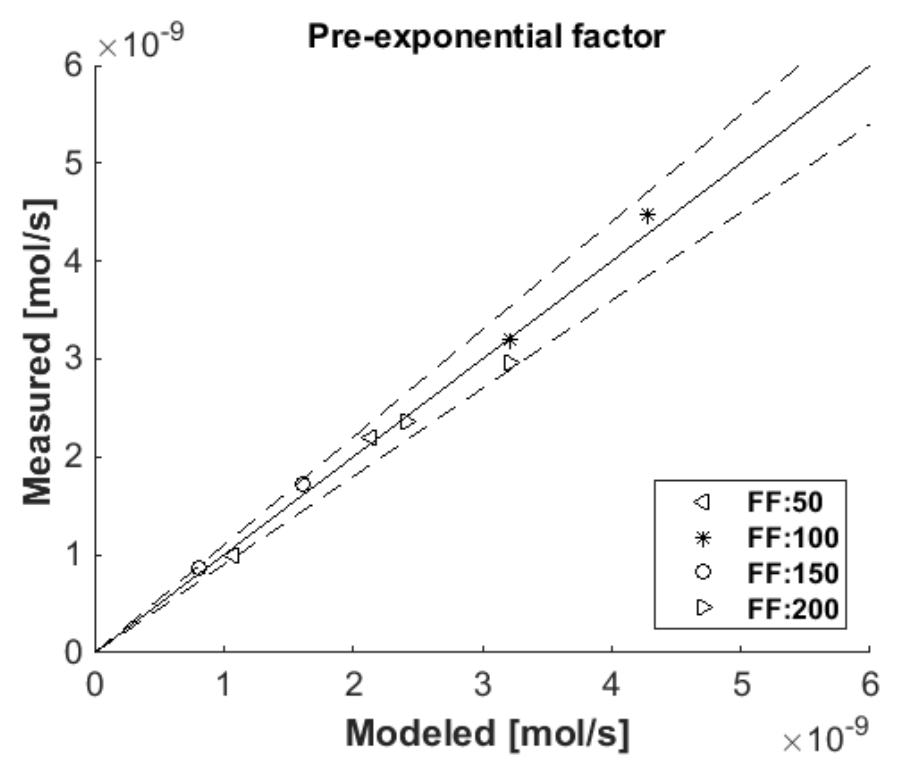

471 Fig. 6. The result of the pre-exponential factor model (eq. 11) at $P>6$ bar. The dashed lines show the $15 \%$ error range.

474 The values at $\mathrm{P}=6$ bar are not presented due to membrane diffusion limitation at pressures

475 lower than 6 bar. The fitting parameters considering the static models for the permeation zone 476 (eq. 11) are given in Table 3. 


\begin{tabular}{|l|c|c|c|}
\hline Parameter & $\mathrm{k}_{1}$ & $\mathrm{k}_{2}$ & $\mathrm{R}^{2}$ \\
\hline value & 0.602 & $-3.4823 \times 10^{-6}$ & 0.91 \\
\hline Unit & {$\left[\mathrm{mol} . \mathrm{m}^{-2} \cdot \mathrm{Pa}^{-0.5}\right]$} & {$\left[\mathrm{Pa}^{-1}\right]$} & {$[-]$} \\
\hline
\end{tabular}

486 Regarding the value of $k_{2}$, the diverse effect of pressure is obvious (see eq. 11). This is

487 attributed to the fact that at higher pressure, the concentration of hydrogen is higher around the

488 membrane (permeation zone) leading to the lower concentration of the other gases, which

489 directly means that the permeation performance of the membrane is less affected. This is

490 completely in agreement with the experimental results and the assumption of the negative effect

491 of the byproducts of the ESR reactions on the permeation behavior of the Pd-Ag membrane.

493 The result of the Sieverts' law model (permeation zone) is shown in Fig. $7\left(P>6\right.$ bar; $\left.R^{2}=0.86\right)$.

494 The partial pressure of hydrogen in the reactor (obtained based on the molar production rates of 495 the ESR products calculated by the Arrhenius based static model) was used in the Sieverts' law 496 to obtain the pure hydrogen permeation rate. 


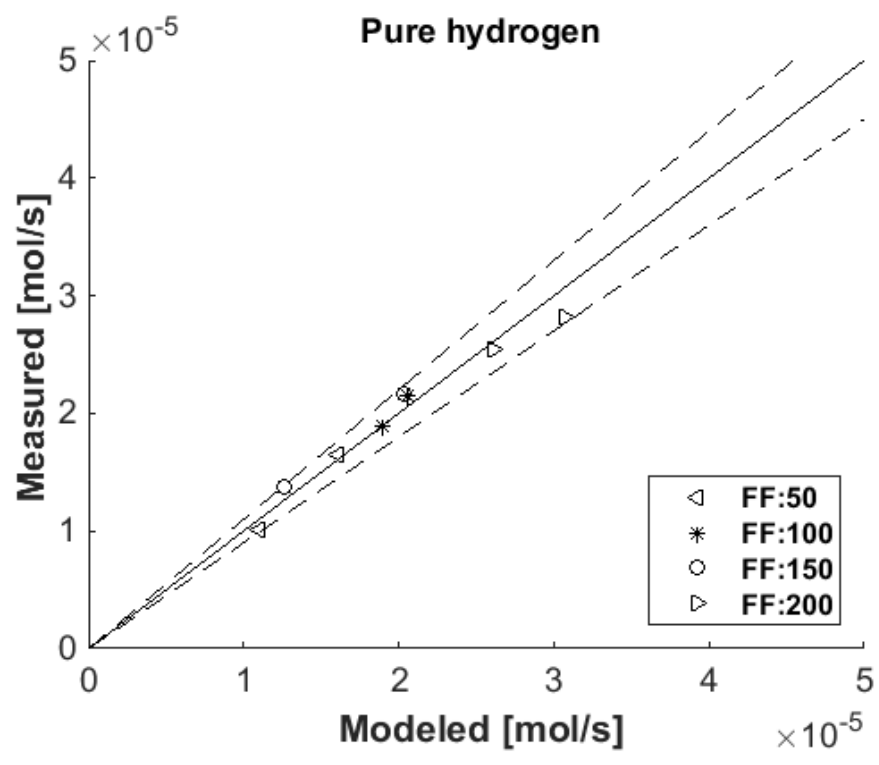

Fig. 7. Parity plots of the hydrogen permeation rate obtained by the Sieverts' law model

\subsection{Isothermal Dynamic simulation}

\subsubsection{Pressure change simulation}

508 To develop the dynamic model of the reforming system in the case of pressure change, firstly,

509 the reactor pressure was simulated. Keeping in mind the configuration of the CMR, when the

510 pressure of the reactor is set at a higher value, the outlet of the reactor is blocked so that the

511 inlet fuel is added to the volume of the reactor to increase the pressure gradually with time.

512 When the pressure is increased, the flow rate of the retentate gas $\left(\dot{m}_{r}\right)$ is zero (see eq. 12$)$. On

513 the contrary, when reactor pressure is set at a lower value, the pressure valve is opened so that

514 gas is released leading to sudden pressure drop in the reactor. The different behavior of the

515 system during pressure increasing and decreasing steps is due to the different act of the 516 pressure controlling system on the pressure valve (see Fig. 1). Therefore, the dynamics of the 
517 system pressure control differ in different steps. The importance of such a performance lies in

518 the dependency of pure hydrogen permeation rate through the membrane on the partial

519 pressure of hydrogen in the reactor. The simulated pressure change behavior of the reformer 520 system is shown in Fig. 8.

521

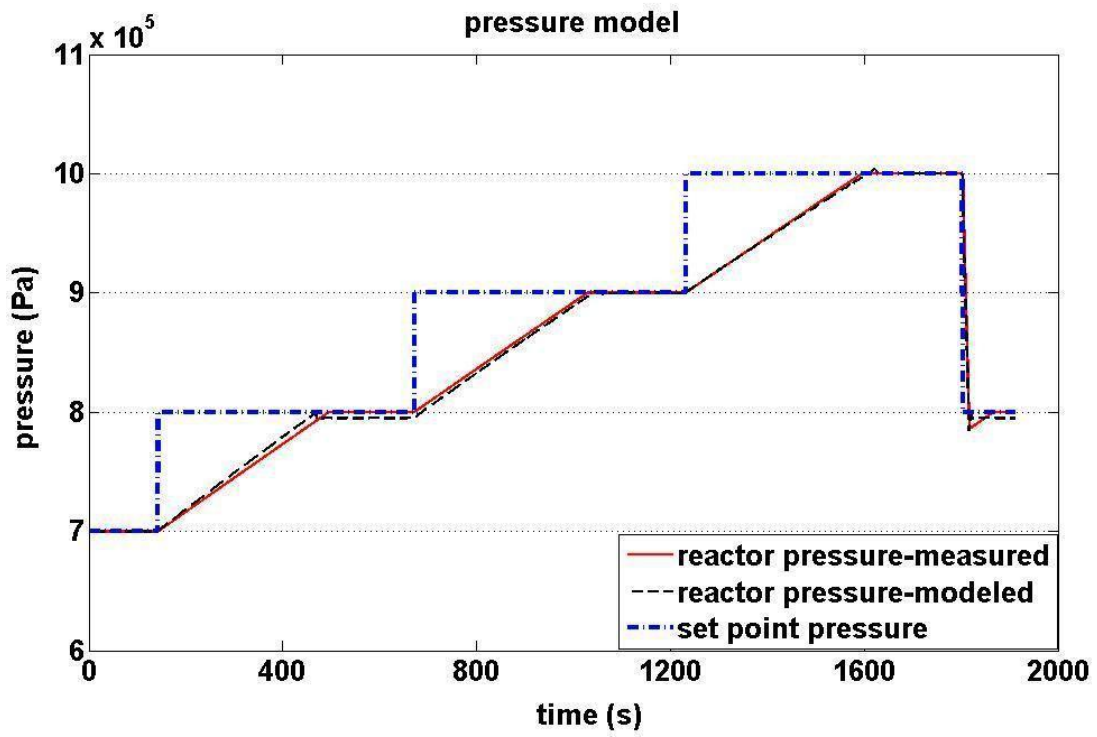

524 Fig. 8. Measured and simulated reactor pressures in the pressure change dynamic tests. $T=923$ $\mathrm{K}, \mathrm{F}_{\mathrm{F}}=200 \mu \mathrm{l} / \mathrm{min}$.

526 It is clear that the results of simulation of reactor pressure by means of the ideal gas law fit the 527 measurement very well.

529 As mentioned before, the hydrogen partial pressure difference at the retentate and permeate 530 sides is the driving force for hydrogen permeation, which is stated by the Sieverts' law (eq. 8).

531 Therefore, consideration of the Sieverts' law as the base of simulation of hydrogen permeation 532 dynamic performance is essential. The simulated dynamic performance of the reforming system 533 in the case of pressure change dynamic tests is shown in Fig. 9. 


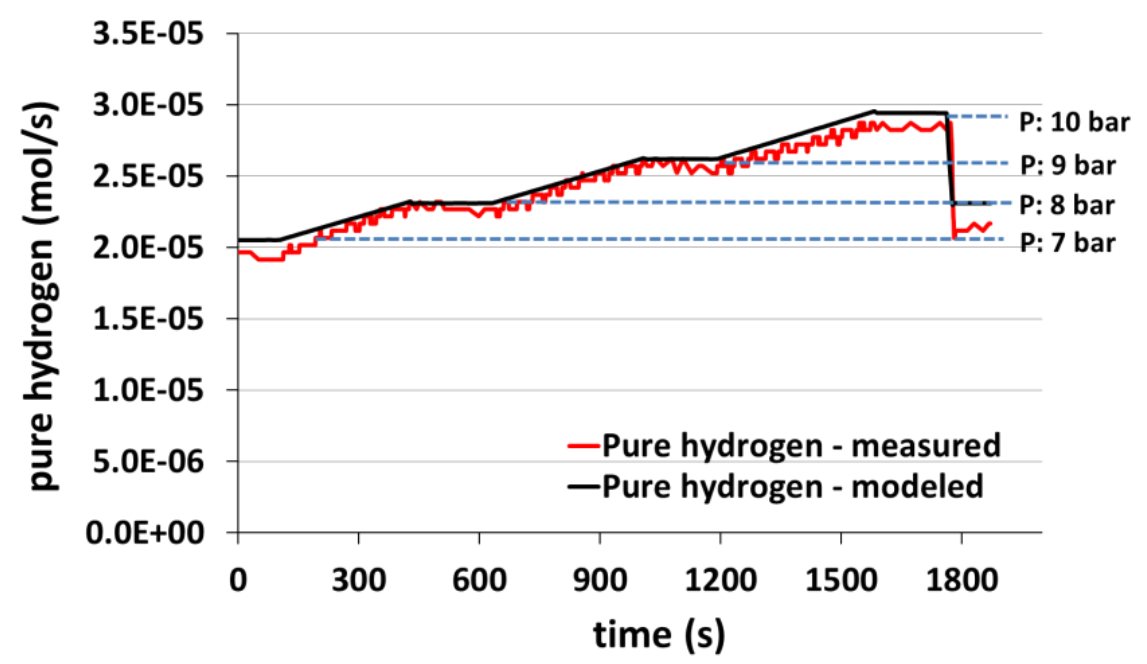

537 Fig. 9. Simulation of the dynamics of the pure hydrogen production rate for pressure change tests. $T=923 \mathrm{~K}, \mathrm{~F}_{\mathrm{F}}=200 \mu \mathrm{l} / \mathrm{min}$.

540 The small fluctuations of the pure hydrogen measurement during the experiments are attributed

541 to the small variations of the pressure inside the reactor, as the pressure valve acts on the outlet

542 retentate stream. This fluctuation is ca. $10^{-6} \mathrm{~mol} / \mathrm{s}$ of pure hydrogen. As expected, at constant

543 temperature and fuel flow rate, pure hydrogen production rate follows the variation of reactor

544 pressure by time. The CMR time constant in the case of pressure change tests was 200

545 seconds. The simulation of the pressure change steps fitted the experimental observation very 546 well, proving the successful modeling and application of the Sieverts' law.

\subsubsection{Fuel flow rate change simulation}

551 In comparison with the pressure change models, it is more essential to develop a model on the

552 fuel flow rate change. The importance of fuel flow rate change model lies in the fact that acting 553 on fuel flow rate is much faster than the operating pressure. The CMR time constant (eq. 14) in 
554 the fuel flow rate change tests was 55 seconds, which is nearly four times shorter than the

555 pressure change tests (200 seconds). The simulation result of the pure hydrogen production 556 rate for fuel flow rate change tests is presented in Fig. 10.

557

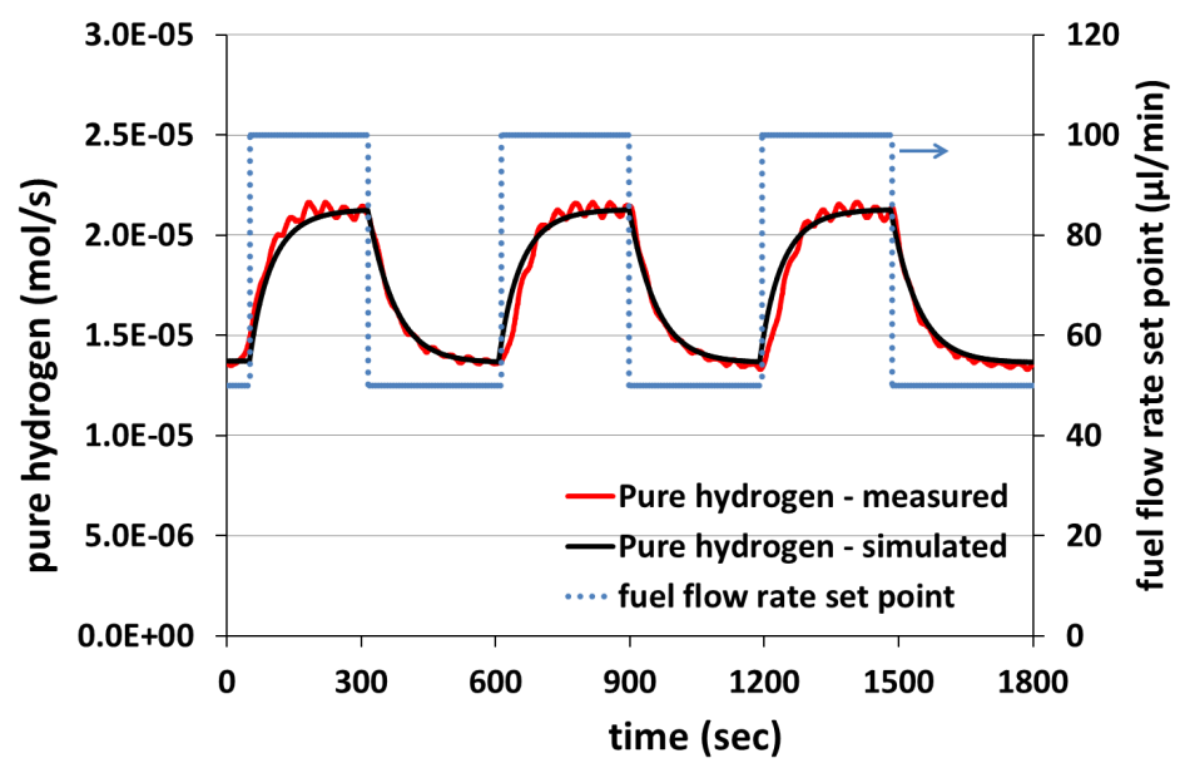

Fig. 10. Simulation of the dynamics of the pure hydrogen production rate for fuel flow rate change tests. $\mathrm{T}=923 \mathrm{~K}, \mathrm{P}=10$ bar.

563 The Sieverts' law simulation results in the case of the fuel flow rate change (Fig. 10) fitted very

564 well to the experimental observation. This is an outstanding result since the accuracy of the

565 prediction of the pure hydrogen dynamics together with fast response of the reforming system to

566 the fuel flow rate adjustments can build up a robust essential step toward further control studies.

568 The isothermal dynamic simulation of pure hydrogen production via ESR in the CMR

569 considering the fuel flow rate and pressure changes can play an essential role for a general 570 model of the dynamic performance of the system when connecting to a fuel cell for its online 571 feeding and control. The simulations presented in this work were able to predict the dynamics of 
572 hydrogen permeation rate with high accuracy; however, the significance of the simulation based

573 on fuel flow rate modifications lies in the faster response of the reformer to reach the steady

574 state regarding the new set point.

575

\section{4. Conclusion}

578 Ethanol steam reforming (ESR) over $\mathrm{Pd}-\mathrm{Rh} / \mathrm{CeO}_{2}$ catalyst was performed in a $\mathrm{CMR}$ at $923 \mathrm{~K}, 6$ -

$57910 \mathrm{bar}$, and fuel flow rates of 50 to $200 \mu \mathrm{l} / \mathrm{min}$ using a mixture of ethanol and distilled water. A

580 static model was proposed based on the Arrhenius law to calculate the molar production rate of

581 ESR products inside the reactor (catalytic zone). The pure hydrogen production rate at steady

582 state conditions was simulated by means of Sieverts' law model. Finally, the dynamics of the

583 pure hydrogen production rate (permeation zone) in the case of the operating fuel flow rate or

584 pressure set point adjustment was simulated under the ideal gas law assumptions at isothermal

585 conditions. The effective critical factors such as hydrogen partial pressure in the CMR and the

586 influence of the co-existence of the ESR products on the permeation behavior of the membrane

587 were taken into account by the Sieverts' law model. Both pressure and fuel flow rate change

588 steps simulations fitted the experimental values very well. However, the simulation of the

589 dynamics of the fuel flow rate change was more essential, as the system responds much faster

590 to such an adjustment. The future work will be devoted to the simulation of the startup and shut

591 down dynamics, the effect of the composition of the inlet fuel, and the temperature profile aiming

592 to provide a controlling system.

\section{Acknowledgements}

595 Funding from MINECO project ENE2015-63969-R is acknowledged. A.H. gratefully

596 acknowledges Erasmus Mundus Joint Doctoral Program SELECT+. J.L. is Serra Húnter Fellow

597 and is grateful to ICREA Academia program. 


\section{References}

600 [1] Jian Q, Zhao Y, Wang H. An experimental study of the dynamic behavior of a $2 \mathrm{~kW}$ proton exchange membrane fuel cell stack under various loading conditions. Energy 2015;80:740-5.

603

604

[2] Carton JG, Lawlor V, Olabi AG, Hochenauer C, Zauner G. Water droplet accumulation and motion in PEM (Proton Exchange Membrane) fuel cell mini-channels. Energy 2012;39:63-73.

[3] Sharaf OZ, Orhan MF. An overview of fuel cell technology: Fundamentals and applications. Renewable and Sustainable Energy Reviews 2014;32:810-53.

[15] Li A, Liang W, Hughes R. The effect of carbon monoxide and steam on the hydrogen

[4] BOETTNER D. Proton exchange membrane (PEM) fuel cell-powered vehicle performance using direct-hydrogen fueling and on-board methanol reforming. Energy 2004;29:2317-30.

[5] Huang Z-M, Su A, Liu Y-C. Hydrogen generator system using Ru catalyst for PEMFC (proton exchange membrane fuel cell) applications. Energy 2013;51:230-6.

[6] Commission E. Comunication from the commission to the European parliament, the council, the European economic and social committee and the committee of the region. 2011.

[7] Llorca J. Microreactors for the generation of hydrogen from ethanol. In: WH L, VG C, editors. Handbook of sustainable energy, New York, USA: NOVA Publication; 2010, p. 693-9.

[8] Deluga GA, Salge JR, Schmidt LD, Verykios XE. Renewable hydrogen from ethanol by autothermal reforming. Science (New York, NY) 2004;303:993-7.

[9] Philpott BJE. Hydrogen Diffusion Technology, commercial applications of palladium membranes. Platinum Metals Review 1985:12-6.

[10] Koch R, López E, Divins NJ, Allué M, Jossen A, Riera J, et al. Ethanol catalytic membrane reformer for direct PEM FC feeding. International Journal of Hydrogen Energy 2013;38:5605-15.

[11] Hou K, Hughes R. The effect of external mass transfer, competitive adsorption and coking on hydrogen permeation through thin $\mathrm{Pd} / \mathrm{Ag}$ membranes. Journal of Membrane Science 2002;206:119-30.

[12] Unemoto A, Kaimai A, Sato K, Otake T, Yashiro K, Mizusaki J, et al. The effect of coexisting gases from the process of steam reforming reaction on hydrogen permeability of palladium alloy membrane at high temperatures. International Journal of Hydrogen Energy 2007;32:2881-7.

[13] Patrascu M, Sheintuch M. On-site pure hydrogen production by methane steam reforming in high flux membrane reactor: Experimental validation, model predictions and membrane inhibition. Chemical Engineering Journal 2015;262:862-74.

[14] Gallucci F, Chiaravalloti F, Tosti S, Drioli E, Basile A. The effect of mixture gas on hydrogen permeation through a palladium membrane: Experimental study and theoretical approach. International Journal of Hydrogen Energy 2007;32:1837-45. permeability of a Pd/stainless steel membrane. Journal of Membrane Science 2000;165:135-41.

[16] Peters T a., Stange M, Klette H, Bredesen R. High pressure performance of thin Pd- 
$23 \% \mathrm{Ag} /$ stainless steel composite membranes in water gas shift gas mixtures; influence of dilution, mass transfer and surface effects on the hydrogen flux. Journal of Membrane Science 2008;316:119-27.

[17] Amandusson $\mathrm{H}$, Ekedahl L-G, Dannetun $\mathrm{H}$. The effect of $\mathrm{CO}$ and $\mathrm{O} 2$ on hydrogen permeation through a palladium membrane. Applied Surface Science 2000;153:259-67.

[18] Mejdell AL, Chen D, Peters TA, Bredesen R, Venvik HJ. The effect of heat treatment in air on $\mathrm{CO}$ inhibition of a $3 \mu \mathrm{m} \mathrm{Pd}-\mathrm{Ag}(23 \mathrm{wt} . \%)$ membrane. Journal of Membrane Science 2010;350:371-7.

[19] Catalano J, Giacinti Baschetti M, Sarti GC. Influence of the gas phase resistance on hydrogen flux through thin palladium-silver membranes. Journal of Membrane Science 2009;339:57-67.

[20] Barreiro MM, Maroño M, Sánchez JM. Hydrogen permeation through a Pd-based membrane and RWGS conversion in $\mathrm{H} 2 / \mathrm{CO} 2, \mathrm{H} 2 / \mathrm{N} 2 / \mathrm{CO} 2$ and $\mathrm{H} 2 / \mathrm{H} 2 \mathrm{O} / \mathrm{CO} 2$ mixtures. International Journal of Hydrogen Energy 2014;39:4710-6.

[21] Cornaglia L, Múnera J, Lombardo E. Recent advances in catalysts, palladium alloys and high temperature WGS membrane reactors. International Journal of Hydrogen Energy 2015;40:3423-37.

[22] Zhang C, Liu Z, Zhou W, Chan SH, Wang Y. Dynamic performance of a hightemperature PEM fuel cell - An experimental study. Energy 2015;90:1949-55.

[23] García VM, López E, Serra M, Llorca J. Dynamic modeling of a three-stage lowtemperature ethanol reformer for fuel cell application. Journal of Power Sources 2009;192:208-15.

[24] García VM, López E, Serra M, Llorca J, Riera J. Dynamic modeling and controllability analysis of an ethanol reformer for fuel cell application. International Journal of Hydrogen Energy 2010;35:9768-75.

[25] Funke M, Kühl H-D, Faulhaber S, Pawlik J. A dynamic model of the fuel processor for a residential PEM fuel cell energy system. Chemical Engineering Science 2009;64:1860-7.

[26] Jahn H-J, Schroer W. Dynamic simulation model of a steam reformer for a residential fuel cell power plant. Journal of Power Sources 2005;150:101-9.

[27] Stamps AT, Gatzke EP. Dynamic modeling of a methanol reformer-PEMFC stack system for analysis and design. Journal of Power Sources 2006;161:356-70.

[28] Kvamsdal HM, Svendsen HF, Olsvik O, Hertzberg T. Dynamic simulation and optimization of a catalytic steam reformer. Chemical Engineering Science 1999;54:2697706.

[29] LIN S, CHEN Y, YU C, LIU Y, LEE C. Dynamic modeling and control structure design of an experimental fuel processor. International Journal of Hydrogen Energy 2006;31:41326.

[30] Tsourapas V, Sun J, Nickens A. Modeling and dynamics of an autothermal JP5 fuel reformer for marine fuel cell applications. Energy 2008;33:300-10.

[31] López E, Divins NJ, Llorca J. Hydrogen production from ethanol over $\mathrm{Pd}-\mathrm{Rh} / \mathrm{CeO} 2$ with a metallic membrane reactor. Catalysis Today 2012;193:145-50.

[32] Idriss H, Scott M, Llorca J, Chan SC, Chiu W, Sheng P-Y, et al. A phenomenological study of the metal-oxide interface: the role of catalysis in hydrogen production from renewable resources. ChemSusChem 2008;1:905-10. 
[33] Domínguez M, Taboada E, Molins E, Llorca J. Ethanol steam reforming at very low temperature over cobalt talc in a membrane reactor. Catalysis Today 2012;193:101-6.

[34] Hedayati A, Le Corre O, Lacarrière B, Llorca J. Exergetic study of catalytic steam reforming of bio-ethanol over $\mathrm{Pd}-\mathrm{Rh} / \mathrm{CeO} 2$ with hydrogen purification in a membrane reactor. International Journal of Hydrogen Energy 2015;40:3574-81.

[35] Reb Research \& Consulting, accessed on 2015-09-23, http://www.rebresearch.com/ 2015.

[36] Divins NJ, López E, Rodríguez Á, Vega D, Llorca J. Bio-ethanol steam reforming and autothermal reforming in 3- $\mu \mathrm{m}$ channels coated with $\mathrm{RhPd} / \mathrm{CeO} 2$ for hydrogen generation. Chemical Engineering and Processing: Process Intensification 2013;64:31-7.

[37] Hedayati A, Le Corre O, Lacarrière B, Llorca J. Experimental and exergy evaluation of ethanol catalytic steam reforming in a membrane reactor. Catalysis Today 2016;IN PRESS.

[38] López E, Divins NJ, Anzola A, Schbib S, Borio D, Llorca J. Ethanol steam reforming for hydrogen generation over structured catalysts. International Journal of Hydrogen Energy 2013;38:4418-28.

[39] Basile A. Hydrogen Production Using Pd-based Membrane Reactors for Fuel Cells. Topics in Catalysis 2008;51:107-22.

[40] Hla SS, Morpeth LD, Dolan MD. Modelling and experimental studies of a water-gas shift catalytic membrane reactor. Chemical Engineering Journal 2015;276:289-302.

[41] Basile A, Curcio S, Bagnato G, Liguori S, Jokar SM, lulianelli A. Water gas shift reaction in membrane reactors: Theoretical investigation by artificial neural networks model and experimental validation. International Journal of Hydrogen Energy 2015;40:5897-906.

[42] Sanz R, Calles JA, Alique D, Furones L, Ordóñez S, Marín P. Hydrogen production in a Pore-Plated Pd-membrane reactor: Experimental analysis and model validation for the Water Gas Shift reaction. International Journal of Hydrogen Energy 2015;40:3472-84.

[43] Di Marcoberardino G, Sosio F, Manzolini G, Campanari S. Fixed bed membrane reactor for hydrogen production from steam methane reforming: Experimental and modeling approach. International Journal of Hydrogen Energy 2015;40:7559-67.

[44] Iulianelli A, Liguori S, Huang Y, Basile A. Model biogas steam reforming in a thin Pdsupported membrane reactor to generate clean hydrogen for fuel cells. Journal of Power Sources 2015;273:25-32.

[45] Chein RY, Chen YC, Chyou YP, Chung JN. Three-dimensional numerical modeling on high pressure membrane reactors for high temperature water-gas shift reaction. International Journal of Hydrogen Energy 2014;39:15517-29.

[46] Papadias DD, Lee SHD, Ferrandon M, Ahmed S. An analytical and experimental investigation of high-pressure catalytic steam reforming of ethanol in a hydrogen selective membrane reactor. International Journal of Hydrogen Energy 2010;35:2004-17.

[47] Jakobsen, A. H. Chemical Reactor Modeling: Multiphase Reactive Flows. 2nd ed. London: Springer; 2014. 